\title{
Lost city found?
}

Laser-based aerial images of the Honduran rainforest, home to the legend of the lost city of Ciudad Blanca, have revealed two possible ancient villages in the coastal region of Mosquitia. The images, which were commissioned by documentary filmmaker Steve Elkins, add to archaeological knowledge of this poorly understood jungle region, where a lack of roads makes access difficult.

Mosquitia, which borders the Caribbean Sea, was most densely populated from AD 800-1200. Hundreds of archaeological sites have been found in the region by exploration on foot, but that still leaves much to be discovered. Various sources tell of a 'lost city' in the jungle, with elaborately carved white stones or golden idols. Most academics believe the place to be a myth, and note it would be impossible to match a real archaeological site to such a vague legend. But explorers are still drawn to it.

Elkins, who has worked in Mosquitia before, was inspired when he heard about a new technique in archaeology: light detection and ranging. LiDAR directs laser pulses from a slow-flying plane down to the ground; some penetrate the jungle canopy before bouncing back, revealing the detailed topography of the surface below. In 2009, a pioneering LiDAR study was used to explore an ancient city in Belize. Elkins contacted the team behind that work: the National Center for Airborne Laser Mapping (NCALM), based at the University of Houston, USA.

Elkins raised funds and invested about $\$ 200,000$ in a LiDAR survey of Mosquitia, trying to cover regions that had not been explored previously. The NCALM remotesensing team spent about two weeks in 2012 flying over a region of about $5,000 \mathrm{~km}^{2}$. They found two areas, each of about $30-60 \mathrm{~km}^{2}$, with rectangular and linear features that could be buildings and ball courts typical of these types of villages. Elkins and some NCALM scientists discussed their results at the American Geophysical Union Meeting of the Americas in Cancun on 15 May 2013.
NCALM developed their LiDAR technique principally for studying geology and geomorphology. But they say that archaeology is now claiming ever more of their time. The technique, although expensive, is particularly good for mapping known-but-unexplored sites, and identifying small buildings, which are hardest to see on the ground through undergrowth. "Pretty much undergrowth. Pretty muarchaeologist working in tropical rainforest wants us to map their areas," says NCALM scientist Juan Carlos Fernandez Diaz. Elkins plans to confirm and explore the two sites with a team of researchers, including locals and Christopher Fisher, an archaeologist at Colorado State University in Fort Collins who used a LiDAR survey to find his own 'lost city' in central Mexico.

Nicola Jones is a freelance journalist based in Pemberton, British Columbia, Canada.

\section{The journalist's take}

Sometimes the relationship between the media and scientists begins long before discoveries are made. Usually a journalist is invited along by researchers to join their expedition. But sometimes the media leads. This story is an extreme case, where the study was actually initiated and directed by someone in the media. More commonly, scientists can tag along with news crews to hard-to-reach sites.

For journalists, the advantage to having a scientist on board is clear: it provides constant and instant access to advice on where to go or what questions to ask of locals, as well as a character to give consistent, personal commentary throughout the article or show. For scientists, the main advantages are access and cash.

The media can have deep pockets. One researcher, who wishes to remain anonymous, told me that after a natural disaster, television crews may have a budget of $\$ 100,000$ or more, along with contacts to help get seats on government relief flights, to clear bureaucratic hurdles and even make bribes. But these deals can come with trade-offs. Television crews have a very different agenda: they need to visit visually stunning locations, rather than sites of scientific importance, and may never stay in one place long enough for a scientist to collect proper data.

For this study, Elkins happened to know someone who knows the President of Honduras - who, Elkins says, was keen for good news coverage of his country to encourage tourism. This made getting the necessary permits a breeze. Elkins' investment so far of about $\$ 200,000$ for LiDAR and $\$ 200,000$ for production (mostly provided by another film-maker keen to see the project made), blows typical archaeology budgets for this region out of the water. Rosemary Joyce, an archaeologist at the University of California Berkeley who knows Mosquitia well, notes that a 'large' science grant is in the tens of thousands of dollars.
Joyce has been scathing in her blog about the project and its media coverage (http://go.nature.com/QaeJY1), criticising the project for "hyping" the connection to a mythical lost city, announcing the findings before archaeologists have actually visited the sites, and encouraging looting by promoting the notion that archaeological sites are gold mines (even though the actual locations of the new discoveries are being kept secret). These things might have been avoided, she suggests, if the project had been led by a local archaeologist rather than a film-maker.

Personally I feel that Elkins, who holds a Bachelor's degree in Earth science with a minor in archaeology, did due diligence by consulting relevant experts and the literature before the project, and involving archaeologists for the upcoming, onthe-ground fieldwork. But it is true that projects can look very different when the media, rather than scientists, hold the reins - for better or for worse. 